ESJ Humanities

\title{
Examining the Status of English as a Medium of Instruction in Sub-Saharan Africa: A Comparative Study of Botswana and Nigeria
}

\author{
Oris Tom-Lawyer \\ Department of English and Literary Studies, \\ Igbinedion University, Okada, Edo State, Nigeria \\ Michael Thomas \\ School of Education, Liverpool John Moores University, \\ Liverpool, United Kingdom \\ Maureen Sindisiwe Kalane \\ Communication \& Study Skills Unit, \\ University of Botswana, Gaborone, Botswana
}

Doi:10.19044/esj.2021.v17n36p51

Submitted: 14 July 2021

Accepted: 13 September 2021

Published: 31 October 2021
Copyright 2021 Author(s)

Under Creative Commons BY-NC-ND

4.0 OPEN ACCESS

Cite As:

Tom-Lawyer O., Thomas M. \& Kalane M.S. (2021). Examining the Status of English as a Medium of Instruction in Sub-Saharan Africa: A Comparative Study of Botswana and Nigeria. European Scientific Journal, ESJ, 17 (36), 51. https://doi.org/10.19044/esj.2021.v17n36p51

\begin{abstract}
This paper examines the status of English as a medium of instruction in Sub-Saharan Africa (SSA) by comparing how it is taught and learned in Botswana and Nigeria. The paper's argument is based on the premise that learners acquire literacy skills in a familiar language (Williams, 2011). The English language is an official language in the two countries and has been linked to their social, economic and political development (Cholakova, 2015). The aim of the study is to compare the status of English as a medium of instruction in Botswana and Nigeria, identify and examine the implications for its use, and recommend best practice for policymakers in the field. Based on a systematic review of research between 2000 and 2021, the paper identifies several key findings affecting both countries: the insufficient acquisition of literacy skills in English, the need for a language policy review in Botswana, and the need for a thorough review of teacher quality by the governments of both countries if United Nations Sustainable Development Goal (SDG) 4.c is
\end{abstract}


to be achieved by the deadline of 2030. The implications of the review for both countries are that pupils drop out of school as a result of their lack of understanding of English; a non-credit pass in English at the secondary level can hinder students' career progression; English remains parents' educationally preferred language; and policy makers need to have a strategic awareness of how English and other languages are used in their communities for educational purposes.

Keywords: Botswana, English language, medium of instruction, Nigeria, Sub-Saharan Africa

\section{Introduction}

English has become a global language, and from its earlier limited use, has gained currency as the most sought-after language in the modern world. Its development has not been without controversy, however, as some scholars have identified several negative aspects of its rise to hegemony, e.g., viewing it as an imperialist language, while others judge it to be a link to positive socioeconomic developments in a society (Pandarangga, 2015). As a global language, 'English has become the second language of everybody' (Plonski, Teferra \& Brady, 2013, p. 1). It has also become the educationally preferred language in many countries, with an official status that enables its wider use. Indeed, English is currently a medium of instruction in about 54 countries in the world. Some of the benefits of this role include offering speakers enhanced career prospects and educational mobility, while its challenges in the African context relate to non-involvement by parents and the lack of support by government, as well as the potential for mother tongue and cultural loss (Karvonen, 2017). Regardless of the limitations, studies have consistently shown that African parents often prefer their children to use English rather than their mother tongue as the medium of instruction because of its undoubted status (World Bank 2002).

Presently, economic and military hegemony are also associated with linguistic hegemony; most countries in the world use English as a second language and this is a consequence of the former British Empire and the military hegemony of America (Khaiyali \& Akasha, 2018). This is one reason for the existence of anglophone African countries. English is perceived to offer better opportunities and social mobility (Coleman, 2010). The language has traits which make it useful, approachable and adaptable (McGovern, 2019) and consequently, English is the dominant means of communication in economics, politics and education in Africa (Plonski Teferra \& Brady, 2013). The role of English is often double-edged, however, as it plays a unifying as well as divisive role and has led to a division in African societies of the 
powerful, educated elites from lower socio-economic groups, especially in urban areas (Williams, 2011).

The aim of the systematic review undertaken in this paper is to offer the first comparative study of the status of English as a medium of instruction in Botswana and Nigeria and specifically to identify the implications for its use in both countries. The study is based on the premise that learners acquire literacy skills in a familiar language, and this consequently may contribute to quality education in ways that can help alleviate poverty and aid the wider development of their societies (Williams, 2011). While there have been several studies on the status of English as a medium of instruction, the originality of the research in this paper is that a) it is the first to provide a systematic review of research comparing English language teaching and learning in Botswana and Nigeria, and b) it addresses the importance of English as a medium of instruction with respect to the achievement of UN SDGs, which have tended to marginalise or omit reference to multilingualism and the importance of language learning (Salzburg Report 586, 2017).

\section{Background}

Over the course of several centuries many African countries were colonised by European colonial powers. As of 2021, Africa has a total population of $1,361,244,376$, representing $16.72 \%$ of the entire world's population, and is divided into different regions: Eastern Africa, Western Africa, Northern Africa, Middle Africa and Southern Africa- Sub-Saharan Africa (SSA) was discovered by explorers towards the end of the $18^{\text {th }}$ Century (Silue, 2015) and studies show that education in the region is perceived as one of the weakest in the world (Williams, 2011). Most countries in the region are multi-ethnic and multicultural and multilingualism plays a prominent role in the linguistic landscape of the continent. Although research consistently suggests that the continent has the highest number of languages in the world (Guldemann, 2018); this is in fact misleading, as the number of languages in Africa is 2,058 (30\% of the world's languages), while Asia has 2,197 or 33\% (Silue, 2015) (see Table 1).

As the language of administration, the judiciary, government, diplomacy and a symbol of unity in most African countries, English retains its status as the most prestigious language on the continent. Of the 54 countries in Sub-Saharan Africa (Zellers, 2018), 26 currently have English as an official language or co-official language and researchers have predicted that second language users of English will increase from 235 million to 462 million by 2050 (Moulin \& Campos, 2017). The countries in SSA were primarily colonised by the British, French and Portuguese. Nigeria and Botswana were colonised by the British and as a result both countries share similar contexts in terms of the teaching and learning of English. 
Table 1. Languages and Ethnic Groups in Nigeria and Botswana

\begin{tabular}{|c|c|c|c|}
\hline COUNTRY & POPULATION & $\begin{array}{l}\text { ETHNIC } \\
\text { GROUPS }\end{array}$ & LANGUAGES \\
\hline BOTSWANA & $2,317,233$ & $\begin{array}{l}\text { Tswana } \\
\text { (Sestwana) 79\%; } \\
\text { Kalanga 15\%; } \\
\text { Basara 3\%; } \\
\text { Others including } \\
\text { Kaglagadi and } \\
\text { people of } \\
\text { European } \\
\text { ancestry } 7 \% .\end{array}$ & $\begin{array}{l}\text { Setswana } 73 \% \text {; } \\
\text { Shekgalgadi } \\
3.4 \% \text {; English } \\
\text { (official) } 2.8 \% \text {; } \\
\text { Zezuru/Shona } \\
2 \% \text {; Sesarwa } \\
1.7 \% \text {; } \\
\text { Sembukush } \\
1.6 \% \text {; Ndebele } \\
1 \% \text {; } \\
\text { Others } 2.8 \% \text {. }\end{array}$ \\
\hline NIGERIA & $214,028,302$ & 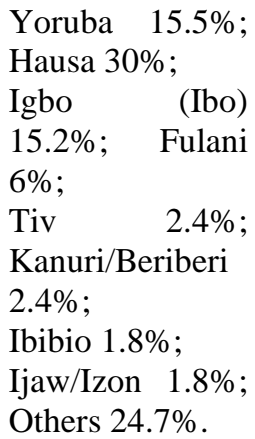 & $\begin{array}{lr}\begin{array}{l}\text { English } \\
\text { (Official); }\end{array} \\
\text { Hausa, } & \text { Igbo } \\
\text { (Ibo); } & \text { Fulani, } \\
\text { over } & 500 \\
\text { additional } & \\
\text { indigenous } & \\
\text { languages. } & \end{array}$ \\
\hline
\end{tabular}

Source: World Fact Book 2021

Originating from the context outlined above, the following research questions will be explored in the study:

1. What are the differences in the provision of English in language education policies of Botswana and Nigeria? This question considers the provision of the language education policies of the two countries. Nigeria possesses three national languages, while Botswana has one. The mother tongue/language of environment is taught for three years in Nigeria and for one year in Botswana.

2. What different challenges confront Botswana and Nigeria in terms of English as a medium of instruction? This question focuses on the problems associated with using English as a medium of instruction in the two countries as several different factors play a role in English use.

3. How does teacher quality inhibit the learning of English as a language of instruction in Botswana and Nigeria? The effects of teacher quality on the teaching and learning of the language will be considered, focusing on the decline in education quality in the two countries against the background in which the government of Botswana has invested considerable sums in education. In 2016, the government invested 10.64 BWP or $28.8 \%$ of the country's budget (Budget Speech, 
2016), while the reverse was the case in Nigeria as funding has decreased. For example, education expenditure dropped from $10.54 \%$ to $7.04 \%$ in the period $2014-2018$ respectively.

4. What are the differences in the prospects of English as a language of instruction in Nigeria and Botswana? This question explores the status of English by examining its perceived status as a gateway to higher education in the two countries.

\section{Methodology}

The methodology is based on a systematic review which considered research conducted between 2000-2021; this period of two decades was necessary as this is the first comparative study between the two countries on the subject. The databases searched included Google Scholar, ResearchGate and Academia.edu. Studies that did not fall within the time span of the research were rejected. In total, 67 empirical and non-empirical publications were chosen, and the themes searched for were shaped by the research questions. Themes such as teacher quality and language education policies, language education policies in Nigeria and Botswana, the challenges of English as a medium of instruction, the prospects of English as a language of instruction and teacher quality in Africa were included. Journal articles, books and monographs, blogs, news media reports, theses and conference papers were reviewed. Table 2 shows that $44(65.67 \%)$ journals, 9 (13.43\%) books and monograph, 1 (1.49\%) blog, 10 (14.93\%), news and reports and $3(4.48 \%)$ theses/conference papers were reviewed.

Table 2. Themes of the Study

\begin{tabular}{|c|c|c|c|c|c|}
\hline Themes & Journals & $\begin{array}{l}\text { Books and } \\
\text { Monographs }\end{array}$ & Blog & $\begin{array}{l}\text { News media } \\
\text { Reports }\end{array}$ & $\begin{array}{l}\text { Theses and } \\
\text { Conference } \\
\text { Papers }\end{array}$ \\
\hline $\begin{array}{l}\text { English as a } \\
\text { global } \\
\text { language }\end{array}$ & $\begin{array}{l}\text { Khaiyali \& } \\
\text { Akasha (2018) }\end{array}$ & $\begin{array}{l}\text { Williams } \\
\text { (2011) }\end{array}$ & & & $\begin{array}{l}\text { Plonski, } \\
\text { Taferra \& } \\
\text { Brady } \\
(2013)\end{array}$ \\
\hline $\begin{array}{l}\text { Language } \\
\text { Education } \\
\text { Policies in } \\
\text { Nigeria and } \\
\text { Botswana }\end{array}$ & $\begin{array}{l}\text { Mokibelo } \\
\text { (2015); } \\
\text { Mokibelo } \\
\text { (2016a); } \\
\text { Mokibelo } \\
\text { (2018); } \\
\text { Makinwija } \\
\text { (2015); } \\
\text { Gwandu \& } \\
\text { Ibrahim } \\
\text { (2016); Tom- } \\
\text { Lawyer \& } \\
\text { Thomas }\end{array}$ & $\begin{array}{l}\text { Kennedy } \\
\text { (2011); } \\
\text { NPE (1998); } \\
\text { British } \\
\text { Council } \\
\text { (2017); } \\
\text { Capstick, } \\
\text { (2018); } \\
\text { Tabuluwa \& } \\
\text { Pansiri, } \\
\text { (2013) }\end{array}$ & & $\begin{array}{l}\text { UNICEF } \\
\text { (2011); } \\
\text { ADEA } \\
\text { (2015); } \\
\text { UNICEF } \\
\text { (2016); } \\
\text { Salzburg } \\
\text { Report 586, } \\
\text { (2017), } \\
\text { World Bank, } \\
\text { (2002); } \\
\text { Botswanan }\end{array}$ & $\begin{array}{l}\text { Jubal } \\
\text { Education } \\
\text { Conference, } \\
(2012)\end{array}$ \\
\hline
\end{tabular}




\begin{tabular}{|c|c|c|c|c|c|}
\hline & $\begin{array}{l}(2020) ; \text { Gorter } \\
\& \quad \text { Cenoz } \\
(2017) ; \\
\text { Ochoma } \\
(2015) ; \\
\text { Tollefson, } \\
(2008) ; \text { Nyati- } \\
\text { Ramahobo, } \\
\text { (2000); } \\
\text { Ogunmodimu } \\
(2015)\end{array}$ & & & $\begin{array}{l}\text { Guardian } \\
\text { (2018) }\end{array}$ & \\
\hline $\begin{array}{l}\text { Challenges } \\
\text { of English as } \\
\text { a medium of } \\
\text { Instruction }\end{array}$ & $\begin{array}{l}\text { Gokmengolu } \\
\& \text { Gelmez- } \\
\text { Burakgazi, } \\
\text { (2013); } \\
\text { Cankaya } \\
\text { (2017) }\end{array}$ & $\begin{array}{l}\text { Dearden } \\
(2015)\end{array}$ & & & \\
\hline $\begin{array}{l}\text { Challenges } \\
\text { of English as } \\
\text { a medium of } \\
\text { Instruction } \\
\text { in Nigeria } \\
\text { and } \\
\text { Botswana }\end{array}$ & $\begin{array}{l}\text { Omowumi } \\
\text { (2019); } \\
\text { Adebayo \& } \\
\text { Folorunsho } \\
\text { (2017); } \\
\text { Ememe } \\
\text { (2009); } \\
\text { Igboanusi \& } \\
\text { Peter (2015); } \\
\text { Uwanyi \& } \\
\text { Omeje (2013); } \\
\text { Adeyemi \& } \\
\text { Kalane } \\
\text { (2011); } \\
\text { Mokibelo } \\
\text { (2016b); } \\
\text { Namuchwa } \\
\text { (2007) }\end{array}$ & & & & \\
\hline $\begin{array}{l}\text { Implications } \\
\text { of English as } \\
\text { a medium of } \\
\text { Instruction } \\
\text { in Nigeria } \\
\text { and } \\
\text { Botswana }\end{array}$ & $\begin{array}{l}\text { Arua \& } \\
\text { Magocha } \\
(2010)\end{array}$ & & & & \\
\hline $\begin{array}{l}\text { Teacher } \\
\text { quality in } \\
\text { Nigeria and } \\
\text { Botswana }\end{array}$ & $\begin{array}{l}\text { Obidike } \\
(2016) ; \\
\text { Moalosi \& } \\
\text { Matsoga } \\
(2016) ; \\
\text { Iloanya } \\
(2014) ; \\
\text { Omotoyinbo }\end{array}$ & & $\begin{array}{l}\text { Ratsatsi } \\
(2005)\end{array}$ & & $\begin{array}{l}\text { Adagiri, } \\
\text { (2009) }\end{array}$ \\
\hline
\end{tabular}




\begin{tabular}{|c|c|c|c|}
\hline & $\begin{array}{l}\text { (2019); Ola- } \\
\text { Busari (2014); } \\
\text { Kolawole, } \\
\text { Olatunji \& } \\
\text { Akanbi } \\
\text { (2015); } \\
\text { Maimela } \\
\text { (2016); } \\
\text { Trudell (2019) }\end{array}$ & & \\
\hline $\begin{array}{l}\text { Teacher } \\
\text { Quality }\end{array}$ & $\begin{array}{l}\text { Gemmell } \\
\text { (2015); Tellez } \\
\text { (2004); } \\
\text { Darling- } \\
\text { Hammond } \\
\text { (2000); } \\
\text { Bolitho } \\
\text { (2015); \& } \\
\text { Dadvand \& } \\
\text { Behzadpoor } \\
\text { (2020); } \\
\text { Blomeke, } \\
\text { Olsen \& Suhl } \\
\text { (2016) }\end{array}$ & $\begin{array}{l}\text { Padwad, } \\
(2015)\end{array}$ & \\
\hline $\begin{array}{l}\text { Prospects of } \\
\text { English in } \\
\text { Nigeria and } \\
\text { Botswana }\end{array}$ & $\begin{array}{l}\text { Igboanusi } \\
(2015) ; \\
\text { Molosiwa } \\
\text { (2020); } \\
\text { Magogwe } \\
\text { (2007); } \\
\text { Kigoto, } \\
\text { (2020) }\end{array}$ & & $\begin{array}{l}\text { Wittenborg, } \\
\text { University of } \\
\text { Applied } \\
\text { Sciences, } \\
\text { (n.d) }\end{array}$ \\
\hline $\begin{array}{l}\text { Prospects of } \\
\text { English }\end{array}$ & $\begin{array}{l}\text { Cholakoya } \\
(2015) ; \\
\text { Graddol } \\
(2000)\end{array}$ & & $\begin{array}{l}\text { Euromonitor } \\
\text { (2015) }\end{array}$ \\
\hline $\begin{array}{l}\text { Languages } \\
\text { in Botswana } \\
\text { and Nigeria }\end{array}$ & & $\begin{array}{l}\text { World Fact } \\
\text { Book (2021) }\end{array}$ & \\
\hline $\begin{array}{l}\text { Sub- } \\
\text { Saharan } \\
\text { African and } \\
\text { Regions of } \\
\text { Africa }\end{array}$ & Silue (2015) & & $\begin{array}{l}\text { Zellars } \\
\text { (2018); } \\
\text { Worldometer } \\
(2021)\end{array}$ \\
\hline
\end{tabular}

\section{Findings and Discussion}

4.1. What are the differences in the provision of English in the language education policies of Botswana and Nigeria?

Educational language policies are signposts that indicate how the target language is to be used as a medium of instruction (Tollefson, 2008). The 
issue of educational language policies is a sensitive and volatile one that needs careful consideration, otherwise sections of society might feel marginalised. Language policy has been viewed as the conscious attempt to alter the use of a community or individual language(s) (Kennedy, 2011). Adapting this definition, educational language policy may be defined as a conscious change in the language(s) used in education

Research demonstrates that an educational system that permits learning in a language that a majority of the learners are unfamiliar with, and a handful of the teachers are proficient in, may lead 'to failure, alienation and waste' (Robinson 2005; Quane 2003; cited in Williams 2011, p. 49). For African countries in particular, this is a point of consideration as it characterises the context of several anglophone African countries. In addition, research suggests that students who are not instructed in their mother tongue may become academically deficient (Salzburg Report, 2017).

Language policies have been described as poor when they do not reflect the situation of the communities involved; they are not financed, executed, encouraged and recognised, neither do they capture end embrace the linguistic situations of the people involved (Salzburg Report 586, 2017).

\subsubsection{Botswana}

Botswana has no single document that enshrines its language education policy (Nyati-Ramahobo, 2000). English is the official language, while Setswana is the national language. Mokibelo (2015) provides an account of the language education policy noting that at independence, Setswana was the medium of instruction from standard one to three (6-9 years), followed by the English language; this position was slightly changed after a review in 1977 by the National Commission on Education in which the commission extended the use of Setswana to standard four (9-10 years) and thereafter English. A further review in 1993/1994 led to the enactment of the current policy. The country recognises two languages at the expense of 28 others (Batibo, 2005; cited in Mokibelo, 2016) and stipulates that Setswana be used as the medium of instruction in standard one (5-6 years), while English is learnt as a subject in standard two (6-7 years) and becomes the medium of instruction (National Policy on Education, 1994).

Scholars have written extensively about the effect of the policy on the education of the learners from marginalised tribes (Makwinja, 2015; Mokibelo, $2015 \& 2018$ ) and the propensity to deny marginalised tribes their 'linguistic human rights' (Philippson \& Skutnabb-Kangas, 2017, p. 24). Tabulawa and Pansiri (2013, p.33) corroborated this view, when they stated that 'ethnic minorities' rather than non-Tswana groups, have no linguistic rights. The policy has impeded learning as pupils who do not understand the languages of instruction have had to drop out of school (Mokibelo, 2018) 
thereby blighting their future in education. It should be noted that the speakers of the minority languages have a right to education in their own languages (May, 2001; cited in Gorter and Cenoz, 2017). In addition, according to Mokibelo (2018), the policy leads to a divide between minority and majority languages. Nevertheless, it is rather unfortunate that policies that are meant to advance the development of a society are stultifying it; this demonstrates that there is a link between language policy and the problems of development confronting African nations (ADEA, 2015), and this is especially evident in the Botswanan context (Kennedy, 2011). As noted by the Salzburg Report (2017), an interesting question worthy of further research is the extent to which this policy has an overtly political dimension, in that it has been created to suppress minorities.

Africa has been identified as a continent in which pupils commence learning in a foreign language (Kennedy, 2011). Therefore, the language policy of Botswana could be termed 'inappropriate' since some pupils commence learning in an unfamiliar national language. In addition, the period of transition from Setswana to English does not allow for the development of competency in their first language. Indeed, it involves a sudden rather than gradual process (The Jubal Language in Education Conference, 2012). Indeed, as Williams (2011) has noted, as a result, the use of English as a medium of instruction in African countries may not lead to developments in human capital. In order to rectify this, strategies that promote the effective teaching of the language should be uppermost in shaping educational policy.

\subsubsection{Nigeria}

Language education policy in Nigeria is a politically sensitive issue considering the diverse population of the country, and as yet, the it has not chronicled its language education policy in a single comprehensive document (Adegbija, 2004). While over 500 languages are currently spoken in Nigeria, the government recognises three national languages - Yoruba, Hausa and Igbo - while English became the official first language and medium of instruction in 1882 (Adetugbo 1979; cited in Ogunmodimu, 2015).

The Educational Language Policy of Nigeria has always revolved around the use of the mother tongue/language of the environment at lower primary school level prior to English becoming more dominant in primary 4 (8-10 years). According to UNICEF (2016), there is a positive link between language education policy and students' schooling, and the benefits of using the mother tongue can be seen in the lower primary in that it promotes participation in classrooms, reduces attrition and ensures involvement in children's education by people and communities.

However, Nigerians pay lip service to this policy in practice, as in urban schools, students mostly commence learning in English due to parental 
preference for the language. Consequently, as Ochoma (2015) suggests, there is a gap between the policy and its implementation in classrooms. The education policy, also referred to as the 'early exit transitional' model, is deficient in two ways, however, most notably in terms of its implementation, which is usually inadequate, and because it lacks academic benefits.

Other problems associated with the policy include the dearth of indigenous language teachers, the lack of materials in indigenous languages and the attitude of learners to indigenous languages as mediums of instruction (Gwandu \& Ibrahim, 2016). Again, the factors that hinder the implementation of the language education policy include non-awareness, multilingual classrooms, the dearth of qualified teachers, the non-availability of relevant materials, government policies that do not include measures to implement policies effectively, the attitude of parents and pupils, the private institutions and early exit (Ochoma, 2015). However, research by the British Council (2017) shows that one prominent issue supporting the implementation of the policy is the attitude of aspirational parents in that perceive English to be the best medium for educational instruction and thus want their children to start learning the language from kindergarten onwards.

\subsubsection{Comparison}

In comparison, Nigeria possesses three national languages, while Botswana possesses one. In Nigeria, the use of mother tongues/languages of environment is usually for three years and thereafter English is used more extensively. In Botswana, the national language is used for one year before English is introduced. Nigeria and Botswana both operate the early exit transition model. The two countries do not have their language education policies catalogued in a single document and thus this is a gap that requires addressing by future research. Finally, the policies are usually not implemented in the urban areas of either country (see Table 3).

\subsubsection{Lessons for Good Practice}

In terms of good practice, several lessons can be drawn from the above discussion. The transitional bilingual model is the most effective teaching model available. The late exit model, which is obtainable in Europe, represents best practice according to UNICEF (2016). Moreover, it is important as Mokibelo, (2016, p. 667) suggests that the 'period of transition is pivotal to subsequent levels of achievement'. 


\begin{tabular}{|c|c|c|c|}
\hline \multicolumn{4}{|c|}{ See Table 3. Educational Policies of Botswana and Nigeria } \\
\hline YEAR & BOTSWANA & YEAR & NIGERIA \\
\hline PRE- 1966 & $\begin{array}{l}\text { Indigenous languages } \\
\text { used as medium of } \\
\text { instruction }\end{array}$ & 1927 & $\begin{array}{l}\text { In lower primary } \\
\text { schools, indigenous } \\
\text { languages are the } \\
\text { medium } \\
\text { instruction }\end{array}$ \\
\hline 1966 & $\begin{array}{l}\text { Setswana to be used } \\
\text { as medium of } \\
\text { instruction from } \\
\text { standard one to three; } \\
\text { thereafter, English is } \\
\text { used }\end{array}$ & 1977 & $\begin{array}{l}\text { The mother tongue or } \\
\text { language of } \\
\text { environment to be the } \\
\text { medium of } \\
\text { instruction }\end{array}$ \\
\hline 1977 & $\begin{array}{l}\text { Setswana to be used } \\
\text { as medium of } \\
\text { instruction from } \\
\text { standard one to four, } \\
\text { while English to be } \\
\text { used from standard } \\
\text { five }\end{array}$ & 1981 & $\begin{array}{l}\text { The mother tongue or } \\
\text { language of } \\
\text { environment will } \\
\text { initially be the } \\
\text { medium } \\
\text { environment, then } \\
\text { English }\end{array}$ \\
\hline 1994 & $\begin{array}{l}\text { Setswana to be used } \\
\text { as medium of } \\
\text { instruction } \\
\text { standard one and } \\
\text { English } \\
\text { standard two }\end{array}$ & 1998 & $\begin{array}{l}\text { In the lower primary, } \\
\text { the language of } \\
\text { environment to be the } \\
\text { medium of } \\
\text { instruction }\end{array}$ \\
\hline & & 2004 & $\begin{array}{l}\text { The language of } \\
\text { environment to be } \\
\text { medium of } \\
\text { instruction for the } \\
\text { first three years, } \\
\text { thereafter English }\end{array}$ \\
\hline & & 2013 & $\begin{array}{l}\text { Every child shall be } \\
\text { taught in the mother } \\
\text { tongue or the } \\
\text { language of the } \\
\text { immediate } \\
\text { community } \\
\text { for the first four years } \\
\text { of basic education' } \\
\text { (including } \\
\text { pre-primary and } \\
\text { Primary 1- Primary } 3\end{array}$ \\
\hline
\end{tabular}

Sources: Mokibelo (2018), Tom-Lawyer \& Thomas (2020) \& British Council (2017). 


\subsection{What different challenges confront Botswana and Nigeria in terms of English as a medium of instruction?}

Countries that were colonised by the British continue to have English as their official language. The same applies to French and Portuguese. These languages have also become languages of instruction in the various countries. English as a medium of instruction has been noted in the private sector of different countries (Dearden, 2015) though its use as a medium of instruction is fraught with challenges.

The challenges of English Medium Instruction (EMI) and English as a Foreign Language (EFL) have been noted by several scholars (Benson, 2004; Hu \& Alsagoff, 2010; Hu, 2007; Deucher, 2006 cited in Mokibelo, 2015 \& Dearden, 2015). Some of the challenges as observed in Uganda include nonparticipation in class by pupils, teacher-centred lessons, code-switching in class and pupils' lack of understanding of the subject matter (Namuchwa, 2007). In addition, Cankaya (2017) enumerated several challenges as observed in Turkey, including the greater amount of time involved in learning (Kirkgoz, 2014), and the potentially negative impact on the motivation of students (Gokmengolu \& Gelmez-Burakgazi, 2013). Most students from minority groups do not achieve full educational outcomes in English (Deuchar, 20006; cited in Mokibelo, 2015). Scholars have also noted that knowledge about the implementation of the policy is vague and that educationalists are unaware of the policy in Nigeria (Benson, 2005; cited in Igboanusi \& Peter, 2015).

On the other hand, MacLeod and Larsson (2011), in a study to determine English influence on Swedish young people among others, noted that:

- Students are familiar with listening to English, and music coupled with television and film are the prime media for learning the language;

- Singing is one informal method of exposure to oral English;

- Students write little English when they are not in the classroom;

- Computers and the Internet are used mostly when English is learnt out of the classroom;

- Students have a feeling that the classroom milieu contributes in a limited way to learning relevant knowledge of English.

The context of their research, which is akin to the situation in most African countries, demonstrates that an effectively implemented approach to EMI can lead to improvements in the English language proficiency of students.

\subsubsection{Botswana}

As indicated in the previous section, English is the official language and a medium of instruction from standard 2 (6-7 years) in Botswana. The status accorded English in the country, consequently, demands that citizens 
should be proficient in the language. According to Adeyemi and Kalane (2011, p. 1), 'Recommendation 31 of the National Policy on Education (1994) emphasises proficiency in the use of English as a tool for effective communication, study and work'. Therefore, English has an established role in the country that is indisputable.

At the primary level, Mokibelo (2014, 2015, 2016a, 2016b) has written extensively on the challenges confronting English as a medium of instruction in rural public primary schools, while examining the language in education policy of Botswana. These include non-participation in lessons, poor understanding, incorrect use of pedagogy, relatively high school dropout rates, how English can demoralise the learners as they exhibit limited expressions in some basic language skills, learners do not achieve learning outcomes on completion of their studies at this level, and the imposition of English on learners can lead to agitation, perplexity and difficulty in reading.

At the secondary level, some of the challenges as identified by Adeyemi and Kalane (2011) include the poor reading skills of students, parental background, dysfunctional libraries, the non-assessment of speaking skills, large class sizes, the competency of teachers and the use of foreignauthor textbooks. As the above challenges indicate, collectively these factors may prevent some learners from acquiring literacy skills in English.

\subsubsection{Nigeria}

English enjoys the status of an official language in Nigeria, and it is the language of the press, the judiciary, administration and government. In Nigeria, English charts the course of life of an individual as it is required for further studies, job opportunities and upward mobility. Every country that recognises it as a medium of instruction has challenges confronting it. However, as noted by Ugwanyi and Omeje (2013), to mitigate these challenges in Nigeria, priority should be given to effective teaching and addressing its decreasing proficiency standards.

Some of the challenges of teaching English at the tertiary level in Nigeria include the interference of the mother tongues of tutors as well as students, and the dearth of educational materials and library resources (Omeme, 2009). Others include the grammatical structure of English, which poses a challenge to learners, the dearth of English specialists, crowded classrooms, the non-availability of textbooks (Ugwanyi \& Omeje, 2013) and reading/learning deficiencies (Adebayo \& Folorunsho, 2017). These challenges are fundamental to the educational system of the country.

In addition, Omowumi (2019) argues that some of the communication problems associated with English as a medium of instruction at the primary level in Nigeria include peer group influence, native language interference and non-standard modelling by teachers. Moreover, the 'educational 
infrastructure' needed for the provision of quality learning in English as a medium of instruction is not available and there are no clear regulations on the teaching of the language (Dearden, 2015).

In summary, research has identified several factors that hinder the development of English as a medium of instruction in Botswana and Nigeria, including mother tongue interference, teachers not being effective role models of English language use, dysfunctional libraries and the complexity of the structure of English. English as a medium of instruction enables social mobility and further studies on this subject are required in both countries to bolster the existing knowledge base. Research suggests that learners do not acquire satisfactory literacy skills in English in either country.

\subsection{How does teacher quality inhibit the learning of English as a medium of instruction in Botswana and Nigeria?}

Quality education is a right of every child and research consistently underlines the importance of teacher quality if students are to perform effectively in English (Obidike, 2016). Research has shown that improvements in teacher efficiency impacts student outcomes positively (Gemmell, 2015) but it is important to support teachers throughout preservice, recruitment and selection, as well as in-service and retention stages of their career trajectory (Reinhardt, 2001; cited in Tellez, 2004).

The quality of the teacher significantly impacts student achievement. According to Darling-Hammond, (2000, p.2) 'measures of teacher preparation and certification are by far the strongest correlates of student achievement in reading and Mathematics'. A teacher, who is poorly prepared and certified will impact student achievement negatively. Indeed, if the quality of initial teacher education is poor, the outcomes of students also tend to be low (Bolitho, 2015). In addition, some of the components of initial teacher education quality include the curriculum structure, motivation of entrants into the initial teacher education programmes and practices of such programmes.

In a study to determine the factors that affect teacher quality implementation, Obidike (2016, p.1) noted that some of the most important practices of teacher quality are 'delivering high-quality student-centred instruction, promoting high levels of student engagement, clear assessment strategies for student learning, using positive behaviour management strategies and evidence of student learning'. This suggests that teacher quality encompasses teacher preparation, certification, recruitment, in-service training, and continuing teacher development. Using Pink's model (2009) as a framework, Padwad (2015) viewed dynamism in teacher motivation and proposed examining teacher motivation form three perspectives: motivation to join the profession, motivation to stay and motivation to grow in the profession. 
In this context, Deci and Ryan's (1985) theory of intrinsic and extrinsic motivation are still valuable. Motivation to join the teaching profession may be extrinsic or intrinsic, which means that the reasons why an individual joins the profession determines whether it was an inner drive or not; intrinsic reasons relate to the love for the profession, while extrinsic relates to joining the profession as a last resort in order to survive. The reasons to stay in the profession are usually extrinsic as there is always the need for survival. If survival is not achieved, teachers are bound to look elsewhere. The need to stay in the profession is typically intrinsic as this is usually a stage of selfactualisation. Therefore, all these factors must be taken into consideration if teacher quality is to be improved

\subsubsection{Botswana}

According to Ratsatsi (2005, p. 1), the impediments to quality education and universal primary education in Botswana are 'teacher attrition mainly due to HIV/AIDS, pre-primary education, in-service training ... and salaries'. Iloanya (2014) asserts that Botswana is in need of well-prepared teachers that are committed to the teaching profession and are capable of delivering quality education to learners as quality in the country's teacher education is a pre-requisite for an efficient schooling process.

The government of Botswana has stated in various policy documents that it is important that quality education is provided (National Policy on Education 1994; Vision 2020; cited in Moalosi \& Matsoga, 2016). This is an important policy consideration for the government as research further reveals that they have allocated significant funds for the development of teachers. However, while this is a priority, a change is recommended in the training of teachers as a decline in students' achievement has been recorded in primary and secondary schools. Moreover, research has shown the link between English language teacher quality and student performance. Indeed, Blömeke, Olsen and Suhl (2016) assert that teacher quality is connected with the quality of instruction, and the quality of instruction is in turn strongly correlated with student outcomes. Similarly, in the Botswanan context, Iloanya (2014) argues that one of the most important ways of improving students' learning outcomes is through improving the quality of teaching.

The quality of entrants entering teacher training colleges is to a large extent a key factor in determining the quality of their graduates. The recognition of teacher quality by the government has enabled it to devise several measures to ensure quality education. One of these is the Textbook Evaluation Committee (TEC) which was established to ensure quality inputs at the elementary level (Maimela, 2016) and to review and approve textbooks in the country (Monyaku \& Mmereki, 2012; cited in Maimela, 2016). 
In addition, to further improve quality, the government has raised the qualification of primary school teachers to the minimum of a diploma/B.Ed. as well as provided incentives to aid teacher recruitment and retention (Maimela, 2016). Further efforts have aimed to reduce large class sizes (Republic of Botswana 1994; cited in Maimela, 2016).

Despite these efforts by the government, Botswanan schools continue to face many challenges. Mokibelo (2015), for example, observed a situation in which teachers who had specialised in two subjects at teacher training for primary level were made to teach all of the subjects in their schools. This predicament certainly affects the teaching of English as the teachers are deficient in the language skills required for effective teaching. In addition, teachers are denied in-service training, and suggestions made by Revised National Policy on Education (1994) with regard to in-service training, have not been implemented (Ratsatsi, 2005) Therefore, to improve the quality of English language performance in students in Botswana, research findings relating to teacher quality will need to be addressed first and foremost.

\subsubsection{Nigeria}

Research also shows that there is a positive link between the quality of teachers and the academic performance of students in Nigeria (Omotoyinbo \& Olaniyi, 2019; Ola-Busari, 2014) and that quality is a prime factor in Nigeria's educational system (Ozuruoke 2006; Omoreghe 2003, Iji 2006; cited in Adagiri, 2009). Scholars have shown that there has been a downturn in education quality over the last three decades (Obidike, 2016) and specifically in the quality of English language teaching and learning in the country (OlaBusari, 2014).

Many factors have been identified to account for this situation; however, the teacher factor has always been indicated as the primary cause. The source of incompetent English language teachers has been attributed to the poor funding of education dating from the latter part of 1980s, which has resulted in a brain drain (Ola-Busari, 2014) as teachers have moved to Britain, America and other European countries in search of greater opportunities for career development and more stability.

Teacher quality encapsulates teacher preparation, certification, recruitment, in-service training, and continuing teacher development; scholars have noted that teachers in Nigeria are poorly trained, and that teachers lack the license to teach the subject. Teachers from different disciplines have been allowed to teach English, and as a result, the recruitment of incompetent teachers has become the norm (Obidike, 2016; Kolawole, Olatunji \& Akanbi, 2015; \& Ola-Busari, 2014). Furthermore, the dearth of language experts (Gwarjiko, 2015) and low achieving entrants into teacher colleges (Amadi, 2013) are also issues that need further consideration. Importantly, teachers are 
denied the opportunity of in-service training (Akinsolu, 2010 cited in Obidike, 2016), and where available, if at all, it is typically inadequate (Trudell, 2019). English language quality in Nigeria has been linked to the competence of the English language teachers, with teachers lacking the proficiency for quality teaching in the language (Ola-Busari, 2014). The inadequacy of teachers is reflected in their inability to use English effectively. This is manifested in their classroom practice of code-switching (Nta et al, 2012, Ezema, 2004; cited in Trudell, 2019). Moreover, the Chief Examiner of the West African Examination Council (WAEC) report $(2003,2004)$ corroborates the fact that the quality of English language teaching in the country is poor, with students not being able to construct basic sentences, with some students lacking the ability to answer comprehension passages.

The continuing professional development of English language teachers is usually a rewarding experience as it leads to an update of pedagogical content knowledge and this may also impact positively on the students as they are taught by competent teachers. However, research shows that most teachers in the country lack opportunities for structured CPD activities, thereby hampering their professional development (Adagiri, 2009).

\subsubsection{Comparison}

In comparison, several key points emerge from our analysis of teacher quality in Botswana and Nigeria. A positive link between teacher quality and student performance has been identified (Omotoyinbo \& Olaniyi, 2019; OlaBusari, 2014; Blömeke, Olsen \& Suhl, 2016), as well as a decline in education quality (Obidike, 2016 \& Moalosi \& Matsoga, 2016). Poor funding of education is an important factor in Nigeria, while the Botswanan government has committed P. 12,8 billion to the development of teachers. Indeed, in the fiscal year 2015/16 to 2017/18 the government of Botswana increased allocations to the education sector from P. 11.8 billion to P. 12.8 billion, while in Nigeria the education expenditure dropped from $10.54 \%$ to $7.04 \%$ in the fiscal years 2014-2018 respectively (Ola-Busari, 2014; Moalosi \& Matsoga, 2016, Statista, 2020 \& UNICEF Botswana, 2017). Teachers without the certification to teach English language are allowed to teach. In Botswana research shows that in a rural area of Kweng West, 50\% teachers in Kaudwane, $37.5 \%$ in Tshwaane, $28.6 \%$ in Khekhenye and $23.5 \%$ in Mantshwabisi were untrained (Ola-Busari, 2014; Mokibelo, 2015), while in Nigeria, most schools advise teachers without a teaching qualification to acquire them.

\subsection{What are the differences in the prospects of English as a medium of instruction in Nigeria and Botswana?}

The future of English is complicated and rarely predictable (Graddol, 2000). English has a positive link with political, social and economic 
development (Cholakova, 2015) and studies have been conducted to demonstrate a significant boost to a nation's economy as a result of an improved status for English (Euromonitor, 2015). Some factors that further consolidate the position of English in the world including the demand for employees who are proficient in the language, the global status of the language, benefits derived from speaking the language, the migration of international students to Europe and the unifying role of English in the world (Cholakova, 2015).

\subsubsection{Botswana}

According to Graddol (2014, p.10) English is now identified as a 'new basic skill that all children need to acquire if they want to participate fully in a 21st-century civil society'. Botswana has not been left behind in this respect as English is the second language in the country.

One prospect of English as a medium of instruction is that it benefits learners to enter local institutions of learning. For example, in Botswana students are expected to pass English to gain admission to secondary and tertiary institutions. Similarly, in the era of globalisation, Botswana sends thousands of students to study for undergraduate degrees up to $\mathrm{PhD}$ in various universities around the world, mainly in the UK, Canada, the USA and Australia under the top achievers' programme. The Botswana Top Achievers' Programme was started in 2010 by Botswana's Ministry of Education and Skills Development in order to help students pursue careers that are of strategic importance in driving economic diversification in the country. When students from the programme apply to universities abroad, since English is not their first language, they are required to provide evidence that they have adequate proficiency in English to successfully undertake their programmes of study through the medium of English. They therefore have to take international tests, such as TOEFL and IELTS to demonstrate their level of proficiency (Molosiwa, 2020). These students generally do well because of their experience of learning English, judging from the top achievers' statistics published by the Ministry of Education annually (BGCSE,2010-2020). Currently these students are also gaining access to universities in other parts of the world such as Asia and Europe, as using English as a medium of instruction to learners whose first language is not English is now a global trend.

Another prospect of English as a medium of instruction is that the language skills acquired extends to international diplomacy. It is evident that once learners finish high school or university and join the labour force, their background in English benefits them in the workplace as English is an official language in Botswana and the language of the government, media, judiciary and commerce. 
Furthermore, official oral engagements such as meetings and workshops are conducted in English, notwithstanding that Botswanans typically speak to each other in Setswana or their other local languages. In addition, in some professions such as the media, public relations, marketing, teaching and career diplomacy, English is recognised as a basic skill required for career progression. There is also prestige attached to proficiency in English and this provides advantages in terms of accessing better employment opportunities. In the areas of global communication, political communication and diplomacy, English proficiency is widely recognised as the passport to effective communication in all fora where ideas are exchanged. This is because English as an international language is used by both government and the civil society to establish and maintain relations between countries globally. Finally, the current trend in Botswana is that families in cities have been more exposed to English due to better economic conditions that characterise urban environments. Due to the development and enhancement of ICT by the government, there is generally access to Internet, smart phones, TV and computers (Isaacs, 2007). In many families, both in urban and rural settings, children are first introduced to English before they are introduced to their parents' mother tongue(s). Parents regard the introduction to English at an early stage as an advantage to their children because there are academic benefits attached to using the language, especially at an early age (Molosiwa 2020). That is why there has been a growth of the private education sector in Botswana as schools introduce English as a medium of instruction immediately on school entry.

\subsubsection{Nigeria}

Several studies have shown the prospects of English as a medium of instruction in Nigeria (Dearden, 2015 \& Euromonitor, 2015). A credit pass in English is a passport for entry into tertiary institutions in the country. It is the language of young people, which further consolidates its position and the future economic development of individuals in Nigeria is strongly related to their proficiency in the language. English speakers typically command higher salaries, and this is reflected in the position of Nigerian graduates with the strongest English language skills, who attain the most senior positions in the country. Nigeria receives 35\% of Foreign Direct Investments (FDI) due to the status of English as a lingua franca and English speakers are in high demand as it aids business growth. The proficiency of Nigerians in English is a boost to the economy and the percentage of English speakers in the country is on the rise. Typically, Nigerian parents have a positive attitude towards English (Dearden, 2015) and degrees from English speaking countries are held in high regard (Euromonitor, 2015). Consequently, most Nigerians migrate to English speaking countries for post-graduate and undergraduate degrees. English is the 
language of the Internet, which makes it a global language and hence the Internet is the basic information medium through which information is accessed and disseminated.

\subsection{Comparison}

A comparison of the prospects has shown that English is a passport to attaining higher education in both countries and fluency is a badge of prestige and status. Graduates from the two countries migrate to English speaking countries for further studies. Indeed, UNESCO asserts that approximately, 900,000 Nigerians are being schooled abroad (ICEF Monitor, 2021). In addition, Nigerian students rank first in terms of the number of Sub-Saharan students studying abroad (Kigoto, 2020) with Nigeria on $10.25 \%$, while Botswanan students account for $2.3 \%$ of the total (Wittenborg, University of Applied Sciences, n.d).

\section{Conclusion}

This paper has made an original contribution to the knowledge base of existing research by providing the first systematic review of the challenges and prospects of English as a medium of instruction in Nigeria and Botswana. It found that there are challenges with the Education Language Policy of Botswana as it causes pupils from marginalised tribes (according to Mokibelo, 2018; Mokibelo \& Moumakwa, 2006; cited in Mokibelo, 2014, in Remote Area Dweller Settlements (RADS), (17-25 students yearly) to drop out of school; specifically, in Standards 1-7 (6-13 years), 85\% of pupils and 15\% of Forms 1-3 (12-15 years) students also dropped out of school. It also noted that the two countries operate the early exit transition model, which does not aid pupils in the acquisition of literacy skills in English. Indeed, as a result of the early transition to a second language, pupils do not gain competence in their mother tongue before transitioning to a second language.

In addition, the language education policies of the two countries are not implemented in urban areas. A fundamental challenge confronting English as a medium of instruction in the two countries is that students do not acquire adequate literacy skills as they are taught in an unfamiliar language. Moreover, teacher quality is an issue that needs to be addressed as without teacher quality English cannot be effectively taught and learnt. However, regardless of these challenges, English has prospects in both countries due to its hegemony in areas of business, education, law and administration.

\subsection{Implications for the use of English as a Medium of Instruction in Nigeria and Botswana}

The use of English as a language of instruction has caused pupils to drop out of school because they do not understand the language. For example, 
research shows that 2,253 students discontinued their education in 2001 (Polelo, 2004; cited in Mokibelo, 2014). Again, the dropout rate in Botswana were $0.6 \%, 0.7 \%$ and $0.8 \%$ in 2013, 2014 and 2015 respectively (Botswana Guardian, 2018). The education language policies in the two countries are not implemented in the urban areas as parents in those regions often prefer to have their children taught in English. Students hardly acquire literacy skills in the language; the case of children in Remote Area Dweller Settlements (RADS) such as Bazezuru, Barsawa and San in Botswana shows that approximately $17-25 \%$ students dropout each year; specifically, in Standards 1-7, 85\% of pupils and 15\% of Forms 1-3 students dropped out of school (Mokibelo, 2016 \& Makwinja, 2015. English is the educationally preferred language by parents in the two countries (Arua \& Magocha, 2010). In Botswana 80\% of parents prefer English in schools to other languages (Arua \& Magocha, 2010), while in Nigeria, $70 \%$ of the parents prefer English as medium of instruction (Amadi, 2012). Overall, teacher quality impacts effective teaching and learning of the language in both countries and is a major factor requiring further policy level changes (Ola-Busari, 2014; Blömeke, Olsen and Suhl, 2016).

\subsection{Recommendations \\ Botswana}

Arising from the findings of this paper, several main recommendations have been identified. For Botswana, the government is recommended to adopt the late exit bilingual model to allow for the transfer of skills from the mother tongue; to facilitate this, 5 years of transition should be allowed. The government needs to review its language education policy in order to address the problems of minority groups. Pupils should be encouraged to learn Sestwana and to develop proficiency in it.

\section{Nigeria}

The government is recommended to shown greater commitment to the effective teaching of the language. Due to the importance of English in Nigeria, teachers require access to effective and lifelong in-service training; this is also an area requiring future longitudinal research. Pupils should have enough time (approximately 6 to 7 years) to develop proficiency in their mother tongues before the transition to international languages. The governments should ensure that pupils are encouraged to learn in their mother tongue in order to ensure an effective transfer of skills.

For both countries, educational policies that lead to effective language curriculum reform are required. English will continue to play a prominent role in Nigeria and Botswana; hence the governments of both countries need to protect and sustain its legitimacy. 


\section{References:}

1. Adegbija, E. (2004). Language policy and planning in Nigeria. Current Issues in Language Planning, 53, 181-264.

2. Adeyemi, D., \& Kalane, M. (2011). English in Botswana junior secondary curriculum. International of Education and Science, 3(2), 119-127.

3. Al-Issa, (2017). Qualities of the professional English language teacher educator: Implications for achieving quality and accountability, Cogent Education, 4(1), 1-17.

4. Al Khaiyali, T., \& Akasha, O. (2018). Hegemony of the empire to the language hegemony: A correlational case of English. International Journal of English Language and Translation Studies, 6(1), 150-161.

5. Amadi, A. (2012). Parents and teachers preferred medium of instruction in primary schools in Enugu, Nigeria. Educational Research and Reviews, 7(28), 632-636.

6. Bolitho, R. (2016). The ingredients of quality in teacher education. In Pickering G., \& Gunashekar, P. (Eds.), Teaching quality in English language teacher education. India, Delhi: British Council.

7. Capstick, T. (Ed) (2018). Language for resilience: Cross-disciplinary perspectives on the role of language in enhancing the resilience of refugees and host communities. London: British Council.

8. Cholakova, M. (2015) The influence of the English language in a multilingual and a monolingual Environment: A comparative approach. European Centre for Research Training and Development, 3, 35-78.

9. Coleman, H. (2010). English in development. London: British Council.

10. Darling-Hammond, L. (2000). Teacher quality and student achievement. Policy Analysis: A Review, 8,1-44.

11. Dearden, J. (2015). English as a medium of instruction: A growing phenomenon. United Kingdom: UK: British Council.

12. Euromonitor. (2015). English quantitative indicators: Cameroon Nigeria, Rwanda, Bangladesh, Pakistan. London: British Council.

13. Graddol, D. (2000). The future of English: A guide to forecasting the popularity of English in the $21^{\text {st }}$ Century. London: The British Council.

14. Guldemann, T. (Ed.). (2018). The languages and linguistics of Africa. Berlin: De Gruyter Mouton.

15. Gwarjiko, U. (2015). Effects of mixed gender streaming on students' performance in English

16. Language: A case study of English as a second language classroom in Niger State, Nigeria. International Journal of Academic Research and Reflection, 3(5), 12-18. 
17. Ibrahim, J., \& Gwandu, S. (2016). Language policy in education in Nigeria: Challenges of multilingual Education and the future of English language. American Research Journal of English and Literature, 2, 1-10.

18. Igboanusi, H., \& P, L. (2015). The language-in-education politics in Nigeria. International Journal Bilingual Education and Bilingualism, 19(5), 1-16.

19. Iloanya, J. (2014) Quality teacher education in Botswana: A crucial requirement for effective teaching and learning. Literacy Information and Computer Journal (LICEJ), 3(2), 1743-1749.

20. Kolawole, C., Olatunji, S., \& Akanbi, O. (2015). Imperatives for successful implementation of English language curriculum in Nigerian secondary schools. In Olawale, O., Kolawole, C., Asagba, B., Osiki, J., \& Jayeoba, A. (Eds.), Educational theory and practice across disciplines: Projecting beyond the $21^{\text {st }}$ Century (pp. 53-70). Ibadan: Faculty of Education, University of Ibadan.

21. Kirkgoz, Y. (2015). Globalization and English Language Policy in Turkey. Educational Policy, 23(5), 663-684.

22. Magogwe, J. (2007). An investigation into attitudes and motivation of Botswana secondary school students towards English, Setswana and indigenous languages. English World-Wide, 28(3), 311-328.

23. Mahmoud, A., \& Thabet, A. (2013) The qualities of the good teacher as perceived by Saudi and Yemeni. Greener Journal of Educational Research, 3(2), 72-79.

24. Makwinja, V. (2015). Thinking in my language to the official languages: What a challenge! A case of the Basarma (Bushman/San) children in Botswana. Second $21^{\text {st }}$ Century Academic Forum at Harvard, 5(1), 1-21.

25. Makwinja, V. (2017). Rethinking education in Botswana: A to overhaul the Botswanan education System. Journal of International Education Research, 13(2), 45-58.

26. Maimela, A. (2016). Factors that influence the performance of students in Botswanan primary schools. Journal of Humanities and Social Sciences, 21(9), 40-53.

27. McGovern, K. (2019). Why did English become a 'global language?' Available http://medium.com why_did_english

28. Mcleod, F., \& Larssn, P. (2011). Exposure to English outside the classroom. Malmo University, Kultur, Sprak, Medier.

29. Moalosi, W. (2016). Teacher education and teacher efficacy, do they match in Botswana Colleges International Journal of Scientific Research and in Education, 9(1), 21-28. 
30. Molosiwa, A. (2020). Language and literacy: Issues in Botswana cultural practices of literacy study. Working Paper. Botswana: University of Botswana.

31. Mokibelo, E. (2014). Why we drop out of school: Voices of San school dropouts in Botswana. The Australian Journal of Indigenous Education, 43(2), 184-194.

32. Mokibelo, E. (2015) The outcomes of learning a foreign language: Cases of rural primary schools in Botswana. US-China Education Review, 5(9), 573-590.

33. Mokibelo, E. (2016a). Implementation of the language in education policy and achieving education For all goals in Botswana primary schools. Universal Journal of Educational Research, 4(1), 157-164.

34. Mokibelo, E. (2016b). Transition from Setswana to English: A policy dilemma. Journal of Language Teaching and Research, 7(4).

35. Mokibelo, E. (2018). Language in education policy, issues and Karl Marx's views in education. International Journal of Scientific Research and Management, 6(4).

36. Nta, E. Oden, S. Egbe, G., \& Ebuta, C. (2012) Optimizing students' performance in English through quality teacher education. Journal of Education and Practice, 3(9).

37. Obidike, N. (2016). Factors affecting teacher quality in primary schools in Awka educational zone in Anambra State. AJOTE, 5(1).

38. Ochoma, M. (2015) Language of instruction in Nigeria: Policy to practice. Global Academy Group, 1-8.

39. Odeniyi, Folorunsho, M. (2017). Reading and learning difficulties in English Language among private and public-school pupils in the Federal Capital Territory (FCT), Nigeria. European Scientific Journal, 13, 163-172.

40. Ola-Busari, J. (2014). The state of English language teaching and Learning in Nigeria and Namibia: Implications for national development. International Journal of Innovative Research and Studies, 7(4), 2119-249.

41. Omotoyinbo, D., \& Olaniyi, F. (2019). Quality of teachers: Effective teaching and learning of English In secondary schools, Akoko North West Local Government, Ondo State. Developing Country Studies, 19(2), 12-27.

42. Omowumi, O. (2019). Communication challenges of teaching in English Language in Nigerian primary education. Journal of Research and Method in Education, 9(6), 18-23.

43. Padwad, A. (2016). Rethinking teacher motivation for professional development. In Pickering, G., \& Gunashekar, P. (Eds), Ensuring 
quality in English language teacher education. India, New Delhi: British Council.

44. Pandarangga, S. (2016). The transformation of English global language in the world, 10(2), 90-96.

45. Phillipson, R., \& Skitnabb-Kangas, T. (2017) Linguistic rights and wrongs. In Skutnabb-Kangas, T., \& Phillipson, R. (Eds), Linguistic rights in critical concepts in language studies. London, Routledge.

46. Plonski, P., Teferra, A., \& Brady, R. (2013). Why are more African countries adopting English as an official Language? Presented at African Studies Association Annual Conference, November Baltimore, Maryland.

47. Silue, S. (2015). Discourse on Linguistic diversity in Africa. International Journal on Human and Cultural Studies, 2(3), 792-807.

48. Tellez, K. (2004). Quality teachers for English language learners: A research synthesis. Hersh Waxman, University of Houston. Publication series.

49. Tembe, J., \& Norton, B. (2011). English education, local languages and community perspectives in Uganda. In Coleman, H. (Eds), Dreams and realities: Developing countries and the English language. London: The British Council.

50. Tom-Lawyer, O., \& Thomas, M. (2020). Re-examining the status of the English Language in Anglophone Western Africa: A comparative study of Ghana and Nigeria. English Linguistics Research, 19(4), 622.

51. Trudell, B. (2017). Language education in Nigeria: A review of policy and practice. Nigeria: British Council.

52. UNICEF (2017). The impact of language policy and practice on children's learning in Botswana. Evidence form Eastern and Southern Africa. Kenya: UNICEF.

53. Williams, E. (2011). Language policy, politics and development in Africa. In Coleman, H. (Ed.), Dreams and realities: Developing countries and the English Language. London: British Council.

54. World Bank (2002). World Bank support for provision of textbooks in Sub-Saharan Africa

55. (1985-2000). African Region Human Development Working Paper Series. Washington, D.C.: World Bank.

56. Worldometers (2021). Subregions in Africa by population (2010). Available www.worldometers.info 